\title{
Municipal Employee Residency Requirements and Equal Protection
}

\author{
Municipal employees ${ }^{1}$ in many American cities must reside ${ }^{2}$ in the \\ city or county as a condition of employment. The residency restric- \\ tions are sometimes imposed by state statute, ${ }^{3}$ but more often by \\ municipal charter, ${ }^{4}$ ordinance ${ }^{5}$ or administrative regulation. ${ }^{6}$
}

1. This Note will not consider the related "officer" residency laws. An officer is one who shares in the vital policymaking or decisionmaking of a governmental unit and exercises some portion of its sovereign powers. For the distinction between municipal "officer" and "employee," see E. McQuillin, The LAw of Municipal Corporations $\$ 12.30$ (rev. 3d ed. 1973). Certain classes of personnel-teachers, policemen, firemen and clerical workers-clearly are not officers. It may be difficult to determine the appropriate category for some municipal workers. The residency litigation discussed in this Note involves only parties who clearly are municipal employees.

Virtually every state and city requires local officers, elective and appointive, to reside within the governmental unit which they serve. The restrictions may be imposed by state constitution or statute (see, e.g., ARK. CoNst. art. 19, § 4; N.Y. Pun. Officers LAw art. 2, $\$ 3$ (McKinney Supp. 1973)) or by city charter provision or ordinance (see, e.g., Boston, Mass., Ordinances of 1973 , ch. $7, \S 1$ A, Oct. 16, 1973). Even cities without municipal employee residency requirements usually bar officers from maintaining a domicile outside their boundaries. Municipal entities with employee residency laws often apply the same ordinance to their officers. See, e.g., CHIcago, Ill., CoDE $\$ \$ 25-30$ (1939).

The major difference between officer and employee residency requirements is that officers serve a political function, as representatives of the people who selected them directly by election or indirectly by appointment. This may constitute a compelling reason for demanding officer residence-"to preserve the basic conception of a political community...." Dunn v. Blumstein, 405 U.S. 330, 344 (1972) (holding that bona fide residence may be required as a condition of political participation as a voter).

2. As used in this Note, the term "residence" is to be equated with domicile (primary place of residence). Municipal employees often have sought to evade residency requirements by maintaining a nominal residence inside the required boundaries and a primary residence outside. The courts have uniformly rejected such maneuvers, construing the term "residence" in ordinances or statutes as meaning "domicile." See, e.g., Mercadante v. City of Paterson, 111 N.J. Super. 35, 266 A.2d 61I (Ch. 1970). The residency ordinances of many cities expressly define residence in terms of domicile. Detroit, Mich., Ordinance No. 327-G, $\$ 2-1-1.2$, June 6, 1968, states: "Residence shall be construed to be the actual domicile of the individual where he normally eats and sleeps and maintains his normal personal and household effects." See also Los Angeles, Cal., Ordinance No. 143,025, Jan. 20, 1972; MilwaukeE, WIS., Charter $\$ 5.02(2)$ (1971).

3. See IND. CODE $\S 19-1-2-1$ (1971); MAss. GeN. Laws ANN. ch. 48, $\$ 58 \mathrm{E}$ (1972), ch. $41, \S 99 \mathrm{~B}$ (1971). Occasionally state law may exempt employees such as police, firemen, sanitationmen, and teachers from local residency requirements. See, e.g., N.Y. PUB. OFFICERS LAW art. 2, § 3 (McKinney Supp. 1973).

4. See, e.g., CincinNati, OHIo, CoDE art XVII, § 1 (1967); NEwark, N.J., Code \$ 2.14-1 (1959).

5. See, e.g., Detroit, Mich., Ordinance No. 327-G, June 6, 1968; Los Angeles, Cal., Ordinance No. 143,025, Jan. 20, 1972; San Jose, Cal., Ordinance No. 16043, Jan. 17, 1972.

6. See, e.g., Nashville, Tenn., Civ. Serv. Comm'n Rules ch. 5, § 1, July 1, 1972; Phoenix, Ariz., Admin. Reg. 2.81, §§ 1-4, Sept. 28, 1972. 
Public workers long have challenged such residency laws. ${ }^{7}$ Their most effective attacks have been in the political arena. Some major cities have revoked residency requirements, ${ }^{8}$ and attempts to impose them elsewhere occasionally have been unsuccessful. ${ }^{9}$ At the same time, several major cities have imposed new residency restrictions, ${ }^{10}$ and others, including New York City, may do so in the near future. ${ }^{11}$

7. Among the oldest municipal employee residency cases are Johnson v. State, 132 Ala. 43, 31 So. 493 (1901) (interpreting an "officer" residency requirement) and Hellyer v. Prendergast, 176 App. Div. 383, 162 N.Y.S. 788 (1917). These and other early cases, however, involved issues of statutory construction, not of constitutional validity. Almost uniformly the state courts construed the residency ordinances or statutes against the plaintiff public employees.

8. Voters in Oakland, Cal., secured repeal of a civil service board rule requiring residence of all applicants for city jobs (Oakland, Cal., Civ. Serv. Bd. Rule $4, \$ 4.03$ (1971)), in a public referendum on Nov. 5, 1974. Interview with James M. Newman, Personnel Director, City of Oakland, June 5 , 1975 (telephone). In July, 1974, Tampa removed its city code provision requiring residence within city limits or within an unincorporated area of the county (TAMPA, FLA., CODE art. I, $\$ 2-2$ (1961)). Letter from Jocelyn W. Elkes, Deputy Personnel Director, City of Tampa, Sept. 9, 1974. (All letters in this Note were written to Glenn M. Reiter and are on file with the Yale Law Journal.) Omaha and Norfolk likewise eliminated city residency requirements. Omaha, Neb., Ordinance No. 26992, Nov. 6, 1973; Ordinance to Repeal $\$ \$ 2-22.1$ to -22.4 of the Code of the City of Norfolk, Virginia, 1958, Relating to Residency Requirements for Certain Officers and Employees of the City, June 30, 1972. Jacksonville, Long Beach and Cleveland constitute other major cities which no longer insist upon residence. Jacksonville, Fla., Civ. Serv. Bd. Bull. No. 2-172, Jan. 17, 1972; letter from City Clerk, City of Long Beach, Cal., Aug. 1, 1974; letter from Mercedes Cotner, City Clerk, City of Cleveland, June 24, 1974.

9. Three bills concerning municipal employee residency were introduced in 1972 in the Baltimore City Council but failed to pass. Letter from C. O. Strickler, Librarian, Dep't of Legislative Reference, City of Baltimore, Md., June 25, 1974. One of these bills was especially novel: it provided for a salary decrease of 10 percent, or a reduction in job grade, for any resident city employee who removed his residence from the city. Bill Nos. 397, 398, 399, City Council of Baltimore, Md., June 12, 1972. The Georgia state legislature rejected a bill in 1973 requiring Atlanta policemen to live within the city. Letter from Jessy C. Bearden, Deputy Clerk of Council, City of Atlanta, June 24, 1974.

10. Los Angeles added a city residency requirement to its administrative code in 1972, and New Orleans established a county residency rule in 1973. Los Angeles, Cal., Ordinance No. 143,025, Jan. 20, 1972; New Orleans, La., Ordinance No. 5240, Aug. 27, 1973. Other major cities, including Birmingham, San Antonio, San Francisco, San Jose and Toledo, have reenacted their residency requirements with minor amendments. Birmingham, Ala., Ordinance No. 68-32, June 15, 1968; San Antonio, Tex., Ordinance 35,501, June 8, 1967; San Francisco, Cal., Ordinance No. 204-71, Aug. 6, 1971, as amended, No. 290-71, Nov. 23, 1971; San Jose, Cal., Ordinance No. 16043, Jan. 17, 1972; Toledo, Ohio, Charter ch. V, $\$ 61$ (1972).

11. New York City soon may reinstate a city residency requirement for its employees after a hiatus of 13 years. In 1937 the municipal assembly (now city council) enacted a residency law requiring city domicile, known as the Lyons Law. N.Y. Times, July 14, 1937, at 1, col. 3 . This was repealed in 1962 after intense lobbying by civil service employee unions. N.Y. Times, Mar. 8,1962 , at 25 , col. 5 . In 1974, bills to require residence of all New York City employees were introduced before the New York State legislature. N.Y. Times, Feb. 22, 1974, at 37, col. 7. Assembly Bill No. 10481, Feb. 20, 1974. Although the legislature rejected these bills in May, 1975, the New York City Council sent a "home rule" message to the legislature, requesting the imposition of a residency requirement. N.Y. Times, May 30,1975 , at 35 , col. 3 . Subsequently, the state assembly passed a bill which would require future city employees to live within the city and bar workers now living there from moving outside city limits. N.Y. Times, June 17, 1975, at 20, col. 1. The state senate is expected to act on the residency bill soon, and New York City may rejoin the ranks of major cities with residency requirements for employees. 42,000 of more than 300,000 New York City workers live outside the city. N.Y. 'Times, Feb. 22, 1974, at 37, col. 7. 
When political challenges fail, public employees frequently have turned to the courts to secure the discretion to live where they choose. Most courts have sustained the constitutionality of municipal employee residency requirements, ${ }^{12}$ but some have struck them down. ${ }^{13}$ The Supreme Court has yet to address the issue. ${ }^{14}$

This Note enters the debate ${ }^{15}$ on the constitutional issues raised by municipal employee residency requirements. Part I presents a survey of residency requirements of the 50 largest American cities. Part II proposes the "substantial relation" test as an appropriate equal protection formula for review of residency statutes, ordinances and regulations. Part III applies the test, concluding that residency laws often do not significantly further the purposes attributed to them, and thus may be unconstitutional as a violation of equal protection. Part IV suggests that the invalidation of citizenship requirements for municipal employment in Sugarman v. Dougall ${ }^{16}$ provides a useful analogy for framing the "substantial relation" challenge to residency requirements.

\section{A Survey of Residency Requirements}

Twenty-one of the 50 largest American cities have no statutory residency requirements for employment as a municipal worker. ${ }^{17}$ The

12. The residency requirements of these major cities have been upheld: ChicagoAhern v. Murphy, 457 F.2d 363 (7th Cir. 1972); Detroit-Detroit Police Officers Ass'n v. City of Detroit, 385 Mich. 519 , 190 N.W.2d 97 (1971), appeal dismissed, 405 U.S. 950 (1972); Williams v. Civil Serv. Comm'n, 383 Mich. 50t, 176 N.W.2d 593 (1970); and Newark-Abrahams v. Civil Serv. Comm'n, 65 N.J. 61, 319 A.2d 483 (1974); Kennedy v. City of Newark, 29 N.J. 178, 148 A.2d 473 (1959). Berg v. City of Minneapolis, 274 Minn. 277,143 N.W.2d 200 (1966), sustained a civil service commission residency regulation imposed by the defendant city; the political sequel was the enactment of a regulation expressly authorizing residence outside city limits. Minneapolis, Minn., Civ. Serv. Comm'n Rule 4.05 (1967).

13. See, e.g., Hanson v. Unified School Dist., 364 F. Supp. 330 (D. Kan. 1973); Donnelly v. City of Manchester, 111 N.H. 50, 274 A.2d 789 (1971).

14. The Supreme Court twice has refused to consider challenges to municipal residency requirements. Ector v. City of Torrance, 10 Cal. 3d 129, 514 P.2d 433, 109 Cal. Rptr. 849 (1973), cert. denied, 415 U.S. 935 (1974); Detroit Police Officers Ass'n v. City of Detroit, 385 Mich. 519, 190 N.W. 97 (1971), appeal dismissed, 405 U.S. 950 (1972).

15. Relatively little has been written about municipal employee residency requirements. See Comment, The Constitutionality of Residency Requirements for Municipal Employees, 24 EMory L.J. 447 (1975); Note, Municipal Police Residency Restriction: Rem* nant of Feudalism or Sound Public Policy?, 18 ST. Lous U.L.J. 214 (1973); Note. Residency Requirements for Municipal Employees: Denial of a Right to Commute?, 7 U.S.F.L. REv. 508 (1973); Note, City Employment Residency Requirements, 7 URB. L. ANN. 414 (1974); Note, Constitutional Law-Residency Restrictions Upon Teachers' Right of Travel, 8 LAÑd \& WATER L. Rev. 329 (1973).

16. 413 U.S. $634(1973)$.

17. For a ranking of the 50 largest American.cities by population, see U.S. DEP'T OF Commerce, Statistical ABSTract of THE U.S. $23-25$ (1974). These major cities will be used as a sample for a survey of municipal residency reo irements. The survey was conducted by mail in summer, 1974 , and has been updated since then where indicated. 
other major cities impose varying types of residency requirements. The most prevalent, adopted by 14 cities, demands that all municipal employees be bona fide residents living within the boundaries of the city for the duration of their employment. ${ }^{18}$ Seven cities require municipal employees to reside within the county in which the city is situated. ${ }^{19}$ Another city has a somewhat larger residence zone; its workers may live in the county in which the city is located or in any of the bordering counties. ${ }^{20} \mathrm{~A}$ fourth type of residency requirement

The following cities have no residency requirements (unless otherwise indicated, confirmation provided by letters from city officials named below):

Atlanta-Jessy C. Bearden, Deputy Clerk of Council, June 24, 1974; Baltimore-C. O. Strickler, Librarian, Dep't of Legislative Reference, June 25, 1974; Cleveland-Mercedes Cotner, City Clerk, June 25, 1974; Dallas-W. Lee Armstrong, Ass't City Secretary, July 3, 1974; Denver-Terri McClellan, City Clerk's Office, July 5, 1974; Fort Worth-Office of City Secretary-Treasurer, Aug. 1, 1974; Honolulu-Andrew Muratan, Dep't of Civ. Serv., Aug. 20, 1974; Houston-Joe Weikerth, Civ. Serv. Dep't, July 15, 1974; Jacksonville -N.R. Sharpless, Jr., Personnel Manager, Sept. 3, 1974; Long Beach, Cal.-City Clerk, Aug. 1, 1974; Minneapolis-Minneapolis, Minn., Civ. Serv. Comm'n Rule 4.05 (1967): "Employees of the city may reside outside ... the city, except . . . where the Commission determines the best interests of the city are served by requiring [certain] employees ... to be residents of the city" (letter from John WW. Proctor, Ass't Personnel Director, July 8,1974 , does not indicate that the commission presently requires residence of any classes of employees); New York-Judith Grad, Opinions and Legislative Division, Law Dep't, Aug. 2, 1974; see also N.Y. Pus. OfFICERS LAw art. 2, \$ 3 (McKinney Supp. 1973); N.Y. Times, Feb. 22, 1974, at 37, col. 7; Norfolk-Louis S. Hudgins, City Clerk, July 9, 1974; Oakland, Cal.-interview with James M. Newman, Personnel Director, June 5, 1975 (telephone); Oklahoma City-Patience Latting, Mayor, Aug. 30, 1974; OmahaLarry L. Wewel, Personnel Director, Aug. 5, 1974; Portland, Ore.-George Yerkovich, City Auditor, July 30, 1974; San Diego-City Clerk, July 18, 1974; Tampa-Jocelyn W. Elkes, Dep. Personnel Director, Civ. Serv. Bd., Sept. 9, 1974; Tulsa-City Clerk, Aug. 6, 1974; Wash., D.C.-Ira N. Kellogg, Jr., Ass't Exec. Secretary, Aug. 14, 1974.

18. Buffalo, N.Y., Code ch. $\mathfrak{I}, \S 4$ (1939); Chicaco, Ill., Code $\$ 25-30$ (1939); Detroit, Mich., Ordinance No. 327-G, June 6, I968; El Paso, Tex., CharTer art. X, \$ 16 (1935); Kansas City, Mo., Personnel Rules and Regs. VIII, \$ 8.4 (1974); Los Angeles, Cal., Ordinance No. 143,025, Jan. 20, 1972; Miami, Fla., Ordinance 6945, Dec. 15, 1961, as amended, May 1, 1965; Milwauke,, Wis., City Charter $\$ 5.02$ (1971); Newark, N.J., CODE \$2.14 (1959); Philadelphia, Pa., Ordinance Prescribing Residence Qualifications for Employees in the Civil Service $\$ 2, A$ pr. 16, 1953; Pittsburgh, PA., Charter Ordinance $450, \S 42$ (1902); ST. LouIs, Mo., CodE art. VIII, $\$ 2$ (1960); San Francisco, Cal., Ordinance No. 204-71, Aug. 6, 1971, as amended, Ordinance No. 290-71, Nov. 23, 1971; TolEDo, Ohio, Charter ch. V, $\$ 61$ (1972).

New York state law greatly undercuts the impact of the Buffalo city residency requirement, for employees in the police, fire and sanitation departments and teachers, among others, have been exempted from the local charter provision. N.Y. PUB. Officers $\mathrm{L} A w$ art. 2, $\$ 3$ (McKinney Supp. 1973). The Philadelphia, Pa, city residency ordinance, supra, is typical of a strict continuing residency requirement, stating in part:

Every employee in the Civil Service of the City shall be required to maintain his bona fide residence in the City during the continuance of his employment by the City.

19. Birmingham, Ala., Ordinance 68-32, June 15, 1968; Cincinnatr, OHio, Code art. XVII, \$ I (1967); MEmphis, Tenn., CharTeR \$ 190 (I963); Nashville, Tenn., Civ. Serv. Comm'n Rules ch. 5, \& I (1972); New Orleans, La., Ordinance 5240, Aug. 27, 1973; San Antonio, Tex., Ordinance 35,501, June 8, 1967; San Jose, Cal., Ordinance 16043, Jan. $17,1972$.

One typical county residency regulation, that of San Antonio, Tex., supra, states in part: [B]efore being appointed to a position with the City of San Antonio, [applicants] must reside within [Bexar] County and must continue to reside therein during

their tenure as employees of the City. . . .

20. Coluarus, OHIo, Charter $\$ 158-1$ (1971). 
restricts workers to residence within a specified radius of the city. ${ }^{21}$

Many residency requirements apply only to particular types of employees, typically policemen and firemen. Members of these emergency services may be required to maintain their homes within the city, the county, ${ }^{22}$ a multicounty zone, ${ }^{23}$ or a certain mileage radius of the city. ${ }^{24} \mathrm{~A}$ few cities have "hybrid" residency restrictions for police and firemen. ${ }^{25}$

The residence policies of several major cities do not fall into the categories above. Two cities require certain key nonemergency personnel to live within municipal boundaries, ${ }^{26}$ an extension of the residency regulations affecting only policymaking governmental "officers." ${ }^{27}$ One city uses domicile as a criterion only in hiring by giving official preference to residents. ${ }^{28}$ Other city governments give informal preference to residents in hiring and encourage current employees to maintain city or county residence, even though there are no statutory residence requirements. ${ }^{29}$

While the focus of this survey has been larger cities, many small municipalities have enacted residency restrictions for their civil ser-

21. San Jose allows residence within a 30 -mile radius as an alternative to county residence for all employees. San Jose, Cal., Ordinance 16043, Jan. 17, 1972.

22. Kansas City, Kansas, police and firemen may live within the county, while other employees must live within the city. KANSAS CITY, Kan., CODE $\S 9(3)$ (1973). (Note that Kansas City, Kansas, is not one of the 50 largest cities.)

23. St. Paul, Minn., Ordinance 3250, § 10, Sept. 1, 1973.

24. Mass. Gen. LAwS ANN. ch. 48, §58E (1972), ch. 41, $\$ 99 \mathrm{~A}$ (1971) (mileage radius for police and firemen in Boston and all other Massachusetts cities and towns); Louisville Civ. Serv. Bd. requirement (uncodified either by ordinance or rule-letter from Jerry W. Lee, Job Analyst, Civ. Serv. Bd., Aug. 30, 1974). See IND. Code § 19-1-2-1 (1971).

The radii adopted differ with each city, possibly reflecting the geographical terrain and population density of the metropolitan areas. Compare the Massachusetts residency laws, supra (10 miles) with the Louisville requirement, supra (30 miles). In Lauisville different jobs have different radii; the city utilizes a 20-mile radius for police and a 30 mile radius for firemen. Letter from Jerry W. Lee, supra.

25. Indiana state law requires police and firemen in Indianapolis and other cities to live within the county in which their city of employment is located. Residence must be within 15 miles of city limits as well. IND. CODE \& 19-1-2-1 (1971).

26. Phoenix, Ariz., Admin. Reg. 2.81, $\$$ 1-4, Sept. 28, 1972; Rochester, N.Y., CharTer $\$ 2-17$ (1973). The Phoenix residency requirement affects employees who properly may be called officers, e.g., department heads and their chief assistants, but also includes employees of lesser rank, e.g., certain librarians and administrative assistants.

27. See note 2 supra, for the definition of governmental "officer."

28. Seattle residency rules pertain only to applicants for city jobs, extending an official preference in hiring to residents. SEATTLE, WASH., ChARTER art. XVI, $\$ \$ 6,8,27$ (1962). (However, Washington state statutes prohibit discrimination because of lack of residency in selection of police and firemen. WASH. REv. CODE $\$ \$ 41.12 .075,41.08 .075$ (1972).) Once Seattle employees meet application residency standards, they presumably may migrate outside of the city.

29. Letter from Chuck Gebuhr, Research Director, City-County Council of Indianapolis-Marion County, July 11, 1974 (with respect to nonuniformed services employees); letter from Patience Latting, Mayor, Oklahoma City, Aug. 30, 1974. 
vants. ${ }^{30}$ Reference to residency litigation reveals that some small cities, towns and even villages extend employment to residents only. ${ }^{31}$

\section{The "Substantial Relation" Test and Possible Violation of the Right to Travel}

Residency laws discriminate between two classes of individuals otherwise eligible for municipal employment-residents and nonresidents. Courts ${ }^{32}$ have most frequently questioned residency requirements on the ground that such discrimination may violate the equal protection clause of the Fourteenth Amendment. ${ }^{33}$ There is disagreement, however, as to the proper equal protection formula for testing the permissibility of the discrimination between residents and nonresidents in light of the offered justifications. Some courts have tested the residency laws only by the "minimum rationality" test, ${ }^{34}$ while others have used the standard of "strict scrutiny."

30. Smaller governmental units in the United States seem to insist upon residency as a condition of employment with roughly the same frequency as do the 50 largest cities. Fifty-five percent of all cities have some kind of residency requirement for their employees. See BNA Municipal Yearbook 160 (1967) (table 2); BNA Municipal. YearBOOK 181 (1970) (table 12); BNA Municipal YeARBOOK 187 (1971); Note, Residency Requirements for Municipal Employees: Denial of a Right to Commute?, supra note 15, at 511 n.11, cited in Petitioner's Brief for Certiorari at 13, Ector v. City of Torrance, 415 U.S. 935 (1974).

31. See, e.g., the residency restrictions at issue in Ector v. City of Torrance, 10 Cal. 3d 129, 5I4 P.2d 433, 109 Cal. Rptr. 849 (1973); Quigley v. Village of Blanchester, 16 Ohio App. 2d 104, 242 N.E.2d 589 (1968); Marabuto v. Town of Emeryville, I83 Cal. App. 2d 406, 6 Cal. Rptr. 690 (Dist. Ct. App. 1960).

32. See, e.g., Wright v. City of Jackson, 506 F.2d 900 (5th Cir. 1975); Krzewinski v. Kugler, 338 F. Supp. 492 (D.N.J. 1972); Ector v. City of Torrance, 10 Cal, 3d 129, 514 P.2d 433, 109 Cal. Rptr. 849 (1973); Donnelly v. City of Manchester, 111 N.H. 50, 274 A.2d 789 (1971); Abrahams v. Civil Serv. Comm'n, 65 N.J. 61, 319 A.2d 483 (1974).

33. U.S. CoNsT. amend. XIV, \& 1: "[N]or shall any State... deny to any person within its jurisdiction the equal protection of the laws."

34. The minimum rationality test, the oldest of equal protection standards, simply demands that the legislative classification be a rational means of advancing some permissible legislative purpose. This requirement is easily satisfied and the courts rarely have upheld equal protection challenges under the minimum rationality test. For a detailed discussion of this equal protection test, see Developments in the Law-Equal Protection, 82 HARv. L. REv. 1065 (1969). See also McGowan v. Maryland, 366 U.S. 420 (1961); Lindsley v. Natural Carbonic Gas Co., 220 U.S. 61 (1911). Many of the earlier municipal employee residency cases invoked a minimum rationality test. See, e.g., Kennedy v. City of Newark, 29 N.J. 178, 148 A.2d 473 (1959). The Kennedy court noted: "If there is a rational basis for a residence requirement in furtherance of the public welfare, the constitutional issue must be resolved in favor of the legislative power to ordain it." Id. at 183, 148 A.2d at 476. In Kennedy the selection of this test resulted in the preservation of the challenged ordinance. Several recent municipal employee residency cases similarly have employed a "rational basis" test to uphold such requirements. Ector v. City of Torrance, 10 Cal. 3d 129, 514 P.2d 433, 109 Cal. Rptr. 849 (1973); Abrahams v. Civil Serv. Comm'n, 65 N.J. 6I, 319 A.2d 483 (1974).

35. Under the strict scrutiny equal protection test, legislation which contains a classification deemed to be "suspect" or which impinges upon a "fundamental" right denies equal protection unless there is a compelling state interest advanced by the classification. Relatively few state interests have been held to be compelling. See generally Shapiro v. Thompson, 394 U.S. 618 (1969); Developments in the Law, supra note 
Debate over the appropriate equal protection standard has hinged on whether residency requirements burden any fundamental interest. Once it is determined that a fundamental interest is abridged, a court must invoke strict scrutiny to see whether the abridging law serves a compelling state interest. The right to travel, deemed a fundamental interest under Shapiro $v$. Thompson, ${ }^{36}$ has been held to be abrogated in several cases because residency laws affected the ability of municipal workers to travel outside the city. ${ }^{37}$ Presumably, some resident munici-

34. The Supreme Court has deemed several classifications suspect; they include race (see, e.g., Brown v. Board of Educ., 347 U.S. 483 (1954)) and alienage (see, e.g., Graham v. Richardson, 403 U.S. 365 (1971)). Among the recognized fundamental interests are the right to vote (see Kraemer v. Union Free School Dist., 395 U.S. 621 (1969)) and the right to interstate travel (see, e.g., Shapiro v. Thompson, supra). Several courts in the municipal employee residency requirement context have invoked the strict scrutiny test. See, e.g., Krzewinski v. Kugler, 338 F. Supp. 492 (D.N.J. 1972); Donnelly v. City of Manchester, 111 N.H. 50, 274 A.2d 789 (1971). These courts determined that residency requirements burdened the affected employees' fundamental right to travel. Donnelly invalidated the city residency requirement; Krzewinski determined that the state had a compelling interest in insisting upon the residency of municipal police and firemen.

36. 394 U.S. $618,629-30$ (1968). The right of an individual to move freely from one state to another has long been protected by the Constitution. Crandall v. Nevada, 73 U.S. (6 Wall.) 35, 43 (1867); Williams v. Fears, 179 U.S. 270, 274 (1900); Twining v. New Jersey, 211 U.S. 78, 97 (1908); Edwards v. California, 314 U.S. 160, 180 (1941) (Douglas, $J$, concurring); United States v, Guest, 383 U.S. 745, 757-58 (1965); Shapiro v. Thompson, 394 U.S. 618, 629-30 (1968); Oregon v. Mitchell, 400 U.S. 112, 285 (1970); Dunn v. Blumstein, 405 U.S. 330 (197I); Memorial Hosp. v. Maricopa County, 415 U.S. 250 (1974). In Shapiro $v$. Thompson, the Court declared that

the nature of our Federal Union and our constitutional concepts of personal liberty unite to require that all citizens be free to travel throughout the length and breadth of our land uninhibited by statutes, rules, or regulations which unreasonably burden or restrict this movement.

394 U.S. at 629 .

While the Constitution does not provide explicitly for a right to travel, the Court has anchored this right in several texts: (1) the due process clauses of the Fifth and Fourteenth Amendments: Zemel v. Rusk, 38I U.S. 1, 14 (1965); Aptheker v. Secretary of State, 378 U.S. 500, 505 (1963); Kent v. Dulles, 357 U.S. 116, 125 (1957); Williams v. Fears, supra; (2) the "privileges and immunities" clause (U.S. CoNST. art. IV, \$ 2, cl. 1, amend. XIV): Twining v. New Jersey, supra; Paul v. Virginia, 75 U.S. (8 Wall.) 168, 180 (1868); Corfield v. Coryell, 6 F. Cas. 546, 552 (No. 3230) (C.C.E.D. Pa. 1823); and (3) the commerce clause (U.S. CoNST. art. I, $\$ 8$, cl. 3): Edwards v. California, supra; Crandall v. Nevada, supra at 49 (Clifford, J., concurring).

In light of United States v. Guest, 383 U.S. 745 (1965), debate as to the precise constitutional source of the right to interstate travel may be superfluous. After noting that "there have been recurring differences in emphasis within the Court as to the source of the constitutional right of interstate travel," Guest stated that there was no need "to canvass those differences further" since "[a]11 have agreed that the right exists." 383 U.S. at 759. Similarly, the Shapiro Court found "no occasion to ascribe the source of this right to travel to a particular Constitutional provision." Shapiro v. Thompson, supra at 629-30. See also Note, Residence Requirements after Shapiro v. Thompson, 70 Colum. L. Rev. 134 (1970); Note, Shapiro v. Thompson: Travel, Welfare and the Constitution, 44 N.Y.U.L. REV. 989 (1969).

37. See, e.g., Krzewinski v. Kugler, 338 F. Supp. 492, 498 (D.N.J. 1972); Donnelly v. City of Manchester, 111 N.H. 50, 274 A.2d 789 (1971). See also Abrahams v. Civil Serv. Comm'n, 65 N.J. 61, 77, 319 A.2d 483, 491 (1974) (Pashman, J., dissenting). The right to travel is the only established fundamental interest that courts in residency cases have considered. But Hanson v. Unified School Dist., 364 F. Supp. 330 (D. Kan. 1973), which overturned a county residency requirement, invoked other somewhat dubious "fundamental" interests, viz., the right to work and the right to live where one chooses.

Some courts have refused to accept the notion that residency requirements are a viola- 
pal employees would move out of the city in exercise of their right to travel were it not for the threat of dismissal. ${ }^{38}$

Several courts in municipal employee litigation have argued that the right to travel is not burdened because residency requirements merely obstruct employees' ability to commute. They reason that there is no fundamental "right to commute"39 and that Shapiro involved only migration, ${ }^{40}$ not movement each working day from home to place of employment. Yet the travel involved can be characterized as not merely commutation but migration as well. Residency restrictions prevent relocation of one's family and possessions in much the same sense that concerned the Shapiro Court.

Another attempted distinction has been that Shapiro struck down only the "durational" element of the challenged welfare residency requirements-residence for a certain length of time as a prerequisite to receiving aid. The Shapiro Court did declare that "[t]he residence requirement and the one-year waiting-period are distinct and independent prerequisites." $\$ 1$ Subsequently, Justice Marshall, writing for the majority in Memorial Hospital v. Maricopa County, ${ }^{42}$ stated that only the durational prerequisite for welfare was held to be unconstitutional in Shapiro. A recent municipal employee residency case relied on these statements to uphold a challenged residency restriction. ${ }^{43}$ Yet other courts have found that Shapiro's durational focus is not controlling. ${ }^{44}$ Further, it might be argued that employee residency requirements do impose a type of waiting period or durational requirement-not in the form of a condition precedent upon persons migrating into the city, but as a "condition subsequent" to employment upon persons who would like to migrate out. ${ }^{45}$

tion of the right to travel. See, e.g., Wright v. City of Jackson, 506 F.2d 900 (5th Cir. 1975); Ector v. City of Torrance, 10 Cal. 3d 129, 514 P.2d 433, 109 Cal. Rptr. 849 (1973); Abrahams v. Civil Serv. Comm'n, 65 N.J. 61, 319 A.2d 483 (1974).

38. Krzewinski v. Kugler, 338 F. Supp. 492,498 (D.N.J. 1972).

39. In Ector v. City of Torrance, 10 Cal. 3d 129, 514 P.2d 433, 436, 109 Cal. Rptr. 849 (1973) the court stated:

[A]ppellant is claiming the right to "travel" between his home and his place of employment . . . each working day-in other words, a "right to commute." We cannot discern such a right in the United States Supreme Court decisions . . . .

See also Wright v. City of Jackson, 506 F.2d 900, 902 (5th Cir. 1975).

40. See 394 U.S. at 629 .

41. Id. at 636.

42. 415 U.S. 250,255 (1974).

43. Abrahams v. Civil Serv. Comm'n, 65 N.J. 61, 66-68, 319 A.2d 403, $485-87$ (1974).

44. See, e.g., Krzewinski v. Kugler, 338 F. Supp. 492, $497-99$ (D.N.J. 1972).

45. See Petitioner's Brief for Certiorari at 20, Ector v. City of Torrance, 415 U.S. 935 (1974). The invocation of the right to travel to defeat a continuing residency restriction could open a Pandora's box, for the logical extension of this argument might seem to bar continuing residency requirements in contexts other than public employment. Many public benefits and services, including welfare payments and schools, are tied to the resident status of recipients. 
A third possible ground for distinguishing the employee residency laws is that Shapiro involved interstate rather than intrastate travel. ${ }^{40}$ Admittedly, much of the travel inhibited by employee residence restrictions involves only intrastate migration. Nevertheless, many major American cities are situated close to state lines, and residency requirements in such cities do in fact impede employees' ability to move to homes across the state borders. ${ }^{47}$ In addition, a right to intrastate

However, it may be possible to distinguish municipal jobs from other governmental benefits. When a family moves from one municipal unit to another, its children ordinarily may enroll in the schools of the new locale. Similarly, the welfare recipient, if he exercises his right to travel, will often be able to qualify for benefits in the new jurisdiction. Many welfare programs are state-administered with uniform eligibility standards. See 1 CCH Pov. L. REP. If 1010 (1974); Wedemeyer \& Moore, The American Welfare System, 54 CALIF. L. REv. 326 (1966). Thus intrastate movement need not result in a loss in benefits. Shapiro $y$. Thompson clearly prohibits unreasonable durational residency requirements, which might constitute the principal barrier to placement on the welfare rolls of a new state. 394 U.S, 618 (1969). Here, as with schools, there is little "penalty" for the exercise of the right to travel.

The situation is different when municipal jobs are involved. When a continuing residency requirement causes an employee to lose his job upon exercise of his freedom to travel, he will have to take civil service tests in the new municipal unit, with attendant risk of failure; if the individual passes, he will still have to wait until a job opening occurs. He will lose any seniority and accrued pension benefits attained on his old job. He may be unable to obtain a comparable public job at all, if he happens to move into a municipality which is in the midst of a hiring freeze. The continuing residency requirement thus imposes a considerable penalty on the public employee who decides to utilize his right to travel.

Constitutional rejection of continuing residency requirements in public employment thus need not be used as precedent for similar attacks on residency laws for welfare benefits, schools, parks, police and fire protection, or other local benefits.

46. The Court has not had occasion to decide whether the constitutionally protected right to travel applies to movement from one location to another within the same state. See Wright v. City of Jackson, 506 F.2d 900, 902 (5th Cir. 1975); Abrahams v. Civil Serv. Comm'n, 65 N.J. 61, 69, 319 A.2d 483, 487 (1974) ("[t]he [Shapiro] Court expressly left open the matter of any distinction beween interstate and intrastate travel ..."). In Memorial Hosp. v. Maricopa County, 415 U.S. 250, 255-56 (1974), the Court refused to consider whether there is a right to intrastate travel, even though it had the opportunity to do so. But see King v. New Rochelle Municipal Housing Authority, 442 F.2d 646, 648 (2d Cir.), cert. denied, 404 U.S. 863 (1971); Cole v. Housing Authority, 435 F.2d 807 (1st Cir. 1970). Dicta in Shapiro describes the right to travel in broad tcrms. 394 U.S. at $629-30$. For citizens to be able to travel "throughout . . our land" seemingly would require the extension of the right to travel to an intrastate dimension.

While it may be impossible, and indeed unnecessary, to ascribe the right to travel to a specific clause in the Constitution (see note 36 supra), at least two of the possible sources arguably authorize constitutional protection of intrastate travel. Relatively little commerce is so removed from interstate commerce that it remains outside the regulatory power of the commerce clause. See, e.g., Katzenbach v. McClung, 379 U.S. 294 (1964); Wickard v. Filburn, 317 U.S. 111 (1942). If the right to travel is put on commerce clause footing, it could extend to movement which physically is intrastate but which can be said to affect interstate travel. Similarly, if the due process clauses constitute the foundation for the right to travel, it is difficult to see why intrastate travel should be any less a part of 'ordered liberty' than is interstate travel. Thus there would need to be weighty interests to counterbalance the inhibition of even intrastate travel. See Zemel v. Rusk, 381 U.S. 1 (1965). It is highly questionable whether the objectives of the residency requirements are important enough to justify such inhibition. See pp. 1695-1701 infra. It might be more difficult to make a case for intrastate travel under the privileges and immunities clause.

47. Municipal employees of Philadelphia, for example, would face discharge if they moved to nearby New Jersey or Delaware, states within easy commuting distance. Major American cities located very close to state borders include Chicago, Jacksonville, Kansas 
travel is in a sense a necessary concomitant to a constitutional right to interstate travel, if such protected interstate travel is not peculiarly to stop once the border is traversed. 48

A plausible argument thus can be made that residency requirements abridge the fundamental right to travel so as to invoke the strict scrutiny formula. The Supreme Court, however, has declined to rule on the scope of that right, twice refusing to hear municipal employee residency cases. ${ }^{49}$ The appeal in Detroit Police Officers Association v. City of Detroit" was dismissed "for want of a substantial federal question," 51 which some courts ${ }^{52}$ read as an implicit holding that residency laws do not violate any fundamental rights. Nevertheless, in Detroit Police Officers, the appellants briefed and argued only a claimed "right to live where [one] chooses," rather than the right to travel. ${ }^{53}$ As a response to such a characterization of the employees' interest, the dismissal of Detroit Police Officers need not be taken as certain rejection by the Supreme Court of the applicability of the right to travel. ${ }^{54}$

One means of circumventing the more troublesome dimensions of the right to travel argument against residency laws may lie in the intermediate equal protection test recently developed by the Supreme Court, which requires a level of scrutiny lying between the extremes of minimum rationality and compelling state interest. This "substantial relation" test ${ }^{55}$ entails intensive inquiry into whether a leg-

City, Louisville, Minneapolis, New York City, Newark, Omaha, Philadelphia, St. Louis, St. Paul, Toledo, and Washington, D.C. Of these 13 cities, only five do not require residence of their workers. See note 17 supra. Abrahams v. Civil Serv. Comm'n, 65 N.J. 61,319 A.2d 483 (1974), did not consider the possibility that the Newark ordinance penalized interstate travel between New Jersey and New York.

48. As the Second Circuit noted,

It would be meaningless to describe the right to travel between the states as a fundamental precept of personal liberty and not to acknowledge a correlative constitutional right to travel within a state.

King v. New Rochelle Municipal Housing Authority, 442 F.2d 646, 648 (2d Cir. 1971) (invalidating durational residency requirement for admission to public housing). See also Petitioner's Brief for Certiorari at 14-24, Ector v. City of Torrance, 415 U.S. 935 (1974).

49. See note 14 supra.

50. 405 U.S. 950 (1972).

51. Id.

52. See Ahern v. Mrurphy, 457 F.2d 363 (7th Cir. 1972); Ector v. City of Torrance, 10 Cal. 3d 129, 135, 514 P.2d 433, 436, 109 Cal. Rptr. 849, 852 (1973).

53. Brief for Appellant at 10, Detroit Police Officers Ass'n v. City of Detroit, 405 U.S. 950 (1972).

54. See Note, Residency Requirements for Municipal Employees: Denial of Right to Commute?, supra note 15 , at 530-31.

55. Professor Gunther has provided the fullest discussion of this intermediate equal protection formula. See Gunther, Forward: In Search of Evolving Doctrine on a Changing Court: A Model for a Newer Equal Protection, 86 HARv. L. REv. 1 (1972). He denominates the test as the "means-focused" formula, since the legislative means must bear substantial relation to permissible legislative purposes. This Note, however, will desig- 
islative classification actually furthers the purposes of the challenged law. ${ }^{56}$ Preservation of residency laws under this test would require that such ordinances, statutes and regulations advance substantially ${ }^{57}$ their stated or apparent purposes.

The substantial relation test previously has been applied in situations involving arguably suspect classifications or arguably fundamental rights. The test is useful where important interests lurk under the surface but where the Court is reluctant to commit itself to strict scrutiny in the future by adding to the list of fundamental interests or expanding the scope of interests already denominated as fundamental. ${ }^{58}$ While the municipal employee residency restrictions argu-

nate the test as the "substantial relation" test. This name better describes the central feature of the test, which focuses not so much on the legislative means themselves, as on their relation to their ends.

56. The substantial relation test is the product of recent terms of the Supreme Court. Apparently, the Court has felt uncomfortable with the traditional bifurcated approach to equal protection analysis, especially with the extreme deference required by the minimum rationality formula. The new test seemingly requires less indulgence toward hypothetical explanations of what some reasonable legislature might have had as its purpose, and instead looks at actual purpose. As Professor Gunther notes, "Judicial deference to a broad range of conceivable legislative purposes and to imaginable facts that might justify classifications is strikingly diminished." Gunther, supra note 55 , at 20. Substantial relation analysis usually assumes, however, that the purposes underlying the statutory classification are permissible goals. The Court proceeds to examine whether in fact the legislative means promotes its purported purposes. Id. at 20-24.

The Court has invoked the "substantial relation" test repeatedly since the 1971-1972 term. See, e.g., Jimenez v. Weinberger, 417 U.S. 628 (1974); Kahn v. Shevin, 416 U.S. 351 (1974); Johnson v. Robison, 415 U.S. 361 (1974); Cleveland Bd. of Educ. v. LaFleur, 414 U.S. 632, $651-57$ (1974) (Powell, J., concurring); Vlandis v. Kline, 412 U.S. 441 (1973) (White, J., concurring); San Antonio Independent School Dist. v. Rodriguez, 411 U.S. 1, 70-137 (1973) (Marshall, J., dissenting); James v. Strange, 407 U.S. 128 (1972); Humphrey v. Cady, 405 U.S. 504 (1972); Eisenstadt v. Baird, 405 U.S. 438 (1972); Reed v. Recd, 404 U.S. 71 (1971). See also Sugarman v. Dougall, 413 U.S. 634 (1973) (arguably invoking the intermediate equal protection test); Note, The Irrebuttable Presumplion Doctrine in the Supreme Court, 87 HARv. L. REv. 1534, 1535 n.9 (1973) (noting the continuing vitality of the new test).

57. The issue remains as to how far the legislative classification must further its purposes. Clearly, the substantial relation test is not satisfied if the challenged law only "minimally" advances its objectives, since the new equal protection test reflects Supreme Court disenchantment with the traditional minimum rationality formula. See Gunther, supra note 55, at 20. It is similarly questionable whether "some" rational basis for the classification is enough to satisfy the substantial relation test. Rather, the legislative means must bear a "significant relationship" to the state's purpose (sec Weber v. Aetna Cas. \& Sur. Co., 406 U.S. 164, 175 (1972) (emphasis added)), or must contribute substantially to its achievement (see Reed v. Reed, 404 U.S. 71, 76 (1971)).

The substantial relation test frequently demands empirical evidence showing that the statute promotes its objectives. See Kahn v. Shevin, 416 U.S. 351 (1974); Gunther, supra note 55, at 20-21, 46-48. The test apparently cannot be met by arguments based on hypothetical facts or by reference to conditions that "more likely than not" exist.

58. In Reed $v$. Reed, for example, the Court could have invoked the strict scrutiny test by holding that sex constituted a suspect classification. 404 U.S. 71 (1971). Similarly, in Eisenstadt $v$. Baird, the right to privacy might have been designated an abrogated fundamental right. 405 U.S. 438 (1972). In municipal employee residency litigation, the right to travel could be "expanded" to cover intrastate migration and postappointment residency requirements so as to trigger strict scrutiny. In such instances, however, 
ably penalize the exercise of the right to travel, courts naturally are reluctant to extend the scope of that right. That there still are questions whether freedom to travel includes intrastate migration and whether postappointment residency requirements abrogate that freedom makes the substantial relation equal protection formula particularly appropriate for the question of municipal employee residency requirements.

This Note next seeks to apply the substantial relation test to the major purposes underlying the municipal employee residency requirements. Inquiry will focus primarily on whether these laws promote the objectives of their framers. From a policy perspective, determination that the residency laws may not further the municipal goals also invites suggestion of alternative means of attaining these ends.

\section{Are the Purposes of Residency Requirements Realized?}

The municipal employee residency laws and cases reveal three major purposes for residency requirements: ${ }^{59}$ (a) to enhance the availability of emergency manpower; (b) to protect the public coffer; and (c) to promote identity with the community on the part of city workers. ${ }^{60}$

the availability of the substantial relation equal protection test may make strict scrutiny unnecessary, because the challenged statute will not withstand intermediate scrutiny.

To date, no court in municipal employee residency litigation has explicitly invoked the substantial relation equal protection test. Hanson v. Unified School Dist., $364 \mathrm{~F}$. Supp. 330 (D. Kan. 1973), may have utilized this test, though in a somewhat confusing fashion. Other courts of course have examined whether the residency laws promote their purposes, without making clear the test by which the "fit" of purpose and means would be gauged. See, e.g., Krzewinski v. Kugler, 338 F. Supp. 492, 499-501 (D.N.J. 1972); Donnelly v. City of Manchester, 111 N.H. 50, 52-53, 274 A.2d 789, 791 (1971). See also Abrahams v. Civil Serv. Comm'n, 65 N.J. 61, 88, 319 A.2d 483 (1974) (Pashman, J., dissenting).

59. Local legislative histories or city council minutes, which might reveal most accurately the actual purposes of residency laws, are either nonexistent or else not readily available. Nevertheless, there are some criteria for attributing purposes to the residency requirements. One can analyze (I) the invocation of purposes in litigation supporting stch laws against challenge; (2) the language of the residency laws and the natural consequences of the laws; and (3) comments by public officials and other background information which suggest the motivation for enactment of such requirements. Cf. Note, Legislative Purpose, Rationality, and Equal Protection, 82 YALE L.J. 123 (1972).

60 . Occasionally, rationales other than those in the text are offered in litigation in support of employee residency requirements, though these are often variations on the three major purposes. For a lengthy list of supposed purposes of the residency restrictions, sce Ector v. City of Torrance, 10 Cal. $3 d$ 129, 514 P.2d 433, 109 Cal. Rptr. 849 (1973); Abrahams v. Civil Serv. Comm'n, 65 N.J. 61, 319 A.2d 483 (1974). A favorite tactic of municipal units in residency litigation seems to be the enumeration of a "laundry list" of rationales. Presumably, the hope is that the court will find at least one of the offered purposes acceptable. In Ector the defendant city offered seven rationales, all of which the Supreme Court of California found to have a "rational basis." Ector v. City of Torrance, 10 Cal. 3d at 135, 514 P.2d at 436, 109 Cal. Rptr. at 852. In contrast, the dissenter in Abrahams rejected each purpose on the same list as being without even a rational basis. Abrahams v. Civil Serv. Comm'n, 65 N.J. at 87-90, 319 .1.2d at $497-98$ (Pashman, J., dissenting). 


\section{A. Emergency Manpower}

One of the prime purposes of the residency restrictions is to ensure the availability of emergency manpower. ${ }^{61}$ Many of the requirements apply only to police and firemen, since they are considered the usual source of emergency personnel. ${ }^{62}$ Even for those cities which insist upon the residency of all employees, the emergency manpower rationale probably underlies the restrictions in part. The rationale rests upon two assumptions: that employees living outside the city are farther removed geographically from their place of employment than city residents and are less able to report promptly for emergency duty because of the obstacles posed by heavy traffic, weather or civil disorders. These assumptions have only limited validity.

Some persons living outside the city will live closer to city hall, their precinct or other place of employment than do some city residents. ${ }^{63}$ The assumption that municipal residents live in closer geographical proximity to work would be always true only if the municipal borders were a perfect circle with the place of employment at its center. Many major cities have irregular borders, ${ }^{84}$ while municipal offices, firehouses and other buildings are often scattered throughout the political jurisdiction. ${ }^{65}$ A nonresident, though further from his place of work by air miles, may be closer in road distance or in time. The nonresident may live along a less congested or circuitous route than the resident, or may have more efficient mass transportation available. Factual investigation seems requisite in each case to determine whether or not the residency requirement bears a substantial relation to the emergency manpower objective. ${ }^{66}$

61. In Krzewinski v. Kugler, 338 F. Supp. 492 (D.N.J. 1972), the court gave the following explanation of the "emergency manpower" rationale:

Police and firemen must be able to respond to emergencies timely without fail. It

is precisely during time of natural disaster, riot, or public conflagration that commuting to work would be most difficult.

338 F. Supp. at 499 n.6. The Krzewinski court did not accept the emergency manpower rationale as sufficient. Kennedy v. City of Newark, 29 N.J. 178, 148 A,2d 473 (1959), seems to be the first case to invoke the emergency manpower purpose to sustain $a$ residency requirement. See also Detroit Police Officers Ass'n v. City of Detroit, 385 Mich. 519, 190 N.W.2d 97 (1971); Abrahams v. Civil Serv. Comm'n, 65 N.J. 319 A.2d 483 (1974).

62. See p. 1688 supra. Cities with residency requirements applicable only to police and firemen presumably would be motivated chiefly by emergency manpower considerations.

63. The court in Krzewinski v. Kugler, 338 F. Supp. 492, 499 (D.N.J. 1972), recognized that "geographical proximity cannot logically be equated with municipal borders."

64. See, e.g., RaNd McNally \& Co., Road AtLas 20 (1974) (map of Los Angeles), 70 (map of New York City).

65. New Haven, for example, has its municipal offices situated throughout the city, though many are in the central downtown area. See Soutrern NEw ENGLAND TELETHONE Co., Book of NAMEs: New HAven 252.53 (1974) (listing of City of New Haven municipal offices).

66. The emergency manpower rationale may be somewhat plausible when applied to a narrow class of workers, specifically police and firemen. See notes 22-25 supra. 
A preferred approach to any based solely on political jurisdiction or solely on distance would be a formula combining radius and time. ${ }^{67}$ The city might, for example, require domicile within a specified road mile radius from place of employment coupled with a limit on rush hour commutation time. No city or state has yet employed a temporal element in delineating a permissible residence zone. ${ }^{88}$ Alternatively, the municipality could require the nonresident employee to demonstrate that he has an "adequate" means of transportation into the city $^{09}$ or could set standards for employee availability. Finally, evidenced inability to respond promptly to emergency summonses presumably constitutes just cause for dismissal from the municipal payroll.

\section{B. Public Coffer Theory}

The public coffer rationale ${ }^{70}$ rests on the idea that the resources of a municipality belong to its residents and that residents legitimately are preferred in the distribution of such resources. City residents are said to contribute the tax revenues from which the salaries of workers are drawn; ${ }^{71}$ resident workers are presumed to support the local economy. ${ }^{72}$

But residency laws which apply to all municipal employees are too crudely tailored to further the availability of emergency personnel and should be invalid, under that rationale, because of overinclusiveness. On the character of overinclusive classifications, see Tussman \& tenBroek, The Equal Protection of the Laws, 37 Calif. L. REv. 341, 351.53 (1949). To require a teacher to maintain city domicile because of emergency manpower concerns would be an instance of overinclusiveness, because teachers ordinarily are not called upon to render services in times of civil disorder or disaster. For discussion of overinclusiveness in residency requirements, see Donnelly v. City of Manchester, 111 N.H. 50, 52, 274 A.2d 789, 791 (1971); Abrahams v. Civil Serv. Comm'n, 65 N.J. 61, 88-90, 319 A.2d 483, 498 (1974) (Pashman, J., dissenting).

67. Krzewinski v. Kugler, 338 F. Supp. 492, 499 (D.N.J. 1972), suggests similarly that the "state interest in proximity might be served by a time or distance radius computation."

68. Mapping an acceptable time and radius zone admittedly could be an administrative burden, since reliance on employees' estimates of time and distance might be imprudent.

69. E.g., IND. CODE $\S 19-1-2-1$ (1971), which requires police and firemen to live within the city limits unless they have "adequate means of transportation into [the] city and maintain in [their] residence[s] telephone service with the city." If transportation and telephone service are adequate, then residence within a county/radial zone is permitted. See note 25 supra.

70. For a concise explanation of the public coffer theory, see Krzewinski v. Kugler, 338 F. Supp. 492,498 n.4 (D.N.J. 1972).

71. See, e.g., Donnelly v. City of Manchester, 111 N.H. 50, 52, 274 A.2d 789, 792 (1971). The Donnelly court found this rationale to be unconvincing. Note, however, the debate over a residency law in Denver, as recounted by the Denver City Clerk's Office: "It was recently brought up in a Charter Revision meeting that city and county employees should live within the boundaries since they are being paid by Denver city and county taxes." Letter from Terri McClellan, City Clerk's Office, City and County of Denver, July 5, 1974 (emphasis added).

72. See, e.g., Kennedy v. City of Newark, 29 N.J. 178, 184, 148 A.2d 473, 476 (1959). In the debate over proposed residency legislation in New York, Mayor Beame of New York City argued that the city's economy would benefit from expenditures by resident employees. N.Y. Times, Feb. 22, 1974, at 37, col. 7. 
Yet many cities tax the income of residents and nonresidents alike. ${ }^{73}$ Nonresidents often are subject to other forms of municipal taxation, such as sales or excise taxes. ${ }^{74}$ Residents do not invariably buy more goods and services in the city than do nonresidents. Many cities have bordering suburbs that are relatively undeveloped commercially; suburban residents may depend upon stores in the urban center for major consumer purchases. In addition, city residents who live close to the city limits may prefer shopping in suburban areas because prices and sales taxes are lower or stores are less crowded. In short, the assumption that city residents alone bear the tax burden of the city and advance the local economy must be subjected to factual investigation; residency requirements may lack a substantial relation to the purported public coffer rationale.

Even if it can be shown that the residency requirements do, in fact, further public coffer objectives, the rationale itself may possess only questionable vitality in light of recent judicial attacks. ${ }^{75}$ More-

73. Cities which tax the income earned by nonresidents within city borders and require residence of municipal employees include Cincinnati, Columbus, Detroit, Kansas City, Mo., Philadelphia, Pittsburgh, St. Louis, San Francisco, and Toledo. See Note, Municipal Income Taxes, 28 Acad. Pol. Scr. Proc. 423, 442-45 (1968); Note, Validity of San Francisco's Commuter Tax, 20 Hastnas L.J. 813 (1969).

74. Furthermore, many cities receive substantial revenue from the county, state and federal governments. An employee who lives outside the city may be a resident and taxpayer of these larger jurisdictions. See Hanson v. Unified School Dist., 364 F. Supp. 330,333 (D. Kan. 1973).

75. Inquiry into the constitutional permissibility of the public coffer theory entails a slight divergence from substantial relation analysis, which ordinarily assumes that the legislative purposes are valid. See note 56 supra.

Some courts in residency litigation have questioned whether the public coffer rationale is any longer a permissible governmental purpose. See, e.g., Hanson v. United School Dist., 364 F. Supp. 333 (D. Kan. 1973); Krzewinski v. Kugler, 338 F. Supp. 492 (D.N.J. 1972); Donnelly v. City of Manchester, 111 N.H. 50, 274 A.2d 789 (1971). But see Ector v. City of Torrance, 10 Cal. 3d 129, 514 P.2d 433, 109 Cal. Rptr. 849 (1973); Abrahams v. Civil Serv. Comm'n, 65 Nं.J. 61, 319 A.2d 483 (1974). Such skepticism can be based on language of the Supreme Court which treats the public coffer rationale with some distaste and which arguably may assume the purpose of allocating benefits to individuals according to their tax or economic contribution to be violative of equal protection. See Graham v. Richardson, 403 U.S. 365, 372-75 (1971); Shapiro v. Thompson, 394 U.S. 618, 632-33 (1969); Sugarman v. Dougall, 413 U.S. 634 , 645 (1973).

Graham concerned state statutes which barred aliens from eligibility for welfare benefits. The Court rejected the public coffer theory as a purpose insufficiently compelling to sustain the use of the suspect classification of aliens, stating as well that there was "doubt [about] the continuing validity of the ... doctrine in all contcxts." 403 U.S. at 374 (emphasis added). Though this dictum must be considered in its own context, the broad reach of its language may be intentional.

Shapiro involved state statutes which denied welfare assistance to residents who had not resided within the governmental unit at least one year. Again, the public coffer theory constituted one of the principal rationales in favor of the plan. The state contended that one-year residents should be favored "on the basis of the contribution they have made to the community through the payment of taxes." 394 U.S. at 632. The Shapiro Court, however, rejected the rationale, questioning whether it was a "constitutionally permissible state objective." $I d$. at 633 . The rejection of the public coffer purpose in Shapiro may reach to municipal worker residency requirements as well.

It may be argued that the Court rejected the public coffer doctrine in Graham and 
over, there is no convincing reason to justify allocation of jobs solely on the basis of present tax contributions. Individuals who were longtime inhabitants of a city but recently migrated from it may have contributed more to the municipal unit in tax revenues and consumer expenditures than the new arrival. Finally, what remaining strength the public coffer rationale may have in the case of transfer payments or city services seems less convincing in the case of jobs. If employees are presumed to perform work that justifies the cost of their salaries, then the city loses none of its resources by employing nonresidents.

\section{Community Identity}

A third purpose of municipal employee residency laws is to promote identity with the needs and problems of the city. ${ }^{70}$ Resident employees often are presumed to have a greater stake in the city, providing an incentive for better job performance. ${ }^{77}$ Courts generally have failed to examine critically the validity of such assertions. ${ }^{78}$ Indeed, it is difficult to imagine what kind of evidence a municipality could offer to attest to the psychological identification of resident and nonresident employees. Many nonresidents will once have lived in the city, moving from it only after reaching a middle class income. Family members, former neighbors and friends may still maintain city domicile. Such ties would provide some incentive for efficient

Shapiro only because suspect classifications and violations of fundamental rights were involved. Admittedly, the Graham Court was evaluating the public coffer rationale in light of the suspect classification of alienage (403 U.S. at 372), while the Shapiro Court subjected the statutes to strict scrutiny because they impinged upon the right to travel (394 U.S. at 629-31). If strict scrutiny constitutes the basis for the demise of the public coffer doctrine, the purpose still may retain vitality where courts select a minimum rationality test for examinations of municipal employee residency requirements. But at least one lower court residency requirement opinion has concluded that the public coffer doctrine has "lost not only [its] compelling nature, but also [its] constitutionality." Krzewinski v. Kugler, 338 F. Supp. 492, 498 (D.N.J. 1972).

76. Krzewinski v. Kugler, 338 F. Supp. 492, 500 (D.N.J. 1972), provides the major statement of the "community identity" rationale. See also the following mildly xenophobic editorial printed in the New York Times during debate over the old Lyons residency law (see note 11 supra):

Offhand, a New York school teacher living in Mount Vernon travels only thirty miles a day to Grand Central Terminal. But in the course of a year she travels almost as far as Japan, and how would we like foreigners like the Japanese to come and take charge of our New York school children.

N.Y. Times, June 1, 1937, at 22, col. 4.

77. Ste, c.g., Kennedy v. City of Newark, 29 N.J. 178, 184, 148 A.2d 473, 476 (1959). More recently, Mayor Beame, in pressing for a residency law for New York City workers, contended that resident employees "will have a much greater vested interest in the city"s well-being and consequently will perform their duties with greater urgency and zeal," quoted in N.Y. Times, Feb. 22, 1974, at 37, col. 7 .

78. See, e.g., Ector v. City of Torrance, 10 Cal. 3d 129, 135, 514 P.2d 433, 436, 109 Cal. Rptr. 849, 852 (1973) and Abrahams v. Civil Serv. Comm'n, 65 N.J. 61, 72-73, 319 A.2d 483, 489 (1974), in which the courts made no effort to examine empirical support for the "stake" theory. 
performance by municipal employees. Moreover, the job productivity of employees, which psychological stake is supposed to foster, can be ascertained directly by effective supervision and work evaluation, thus allowing its use in promotion and retention of personnel.

Another theory is that residents know more about the city and and thus are better able to serve it. ${ }^{79}$ Yet current residents who move from the city may be as informed about the city as those who maintain city residence. A more effective means of ensuring adequate knowledge about the municipal unit would be to test such knowledge in appointment examinations. Subsequent education and orientation sessions could supplement employees' knowledge of city problems. It is doubtful whether the residency requirement significantly enhances the acquaintance of city personnel with the problems germane to their jobs.

Some cities view residency restrictions as a way of strengthening rapport between municipal workers and city dwellers, particularly minority groups, so as to lessen misunderstanding and intolerance. ${ }^{80}$ The nonresident is presumed to be less sensitive to or willing to respond to the needs of the city and its inhabitants. ${ }^{81}$ It is assumed that city residents are more distrustful of police or city workers who live outside the municipality.

Yet it is questionable whether residency restrictions significantly increase cooperation. Though employees who migrate to the suburbs have little contact with ghetto areas, resident municipal workers with moderate incomes ${ }^{82}$ also are unlikely to live in the inner cities. $\mathrm{Mu}$ nicipal employees often move to middle class neighborhoods of the city which are similar to suburban settings. Such resident employees may spend little off-duty time outside their own area of the city. ${ }^{83}$

79. See, e.g., Ector v. City of Torrance, 10 Cal. 3d 129, 135, 514 P.2d 433, 436, 109 Cal. Rptr. 849, 852 (1973); Abrahams v. Civil Serv. Comm'n, 65 N.J. 61, 72-73, 319 A.2d 483,489 (1974).

80. See Krzewinski v. Kugler, 338 F. Supp. 492, 499 (D.N.J. 1972); Detroit Police Officers Ass'n v. City of Detroit, 385 Mich. 519, 524, 190 N.W.2d 97, 98 (197I) (Brennan, J., concurring).

81. The Krzewinski court accepted as compelling the state's interest in avoiding spatial "disengagement between work hours and personal life [which] could detrimentally affect the [municipal employee's] attitude toward the community and the people he serves." Krzewinski v. Kugler, 338 F. Supp. 492, 499 (D.N.J. 1972).

82. For policemen with three years on the force, the mean salary in the 20 largest cities is $\$ 11,561$; for firemen, $\$ 11,399$; and for sanitation workers, $\$ 8,137$. INTERNATIONAL City Management Ass'N, The Municipal Year Book 168, 171, 174 (1974). For the base salaries of these employees in individual cities, see $i d$. at 175-77.

83. It has been argued that residency requirements enhance law enforcement by ensuring the presence of off-duty policemen within the city. See Krzewinski v. Kugler, 338 F. Supp. 492, 500 (D.N.J. 1972); Detroit Police Officers' Ass'n v. City of Detroit, 385 Mich. 519, 522-23, 190 N.W.2d 97, 98 (1971). Nevertheless, even nonresident police officers are present within the city during some off-hours, albeit to a lesser degree 
Nor is the distinction between nonresident and resident city workers necessarily important to inhabitants of ghetto areas. Both classes of employees may seem to be relative outsiders who execute the directives of the municipal powers.

There are more direct means, other than residency laws, to attain the laudable objectives of cooperation and trust between city workers and city inhabitants. Some programs have encouraged interaction between municipal employees and local residents. ${ }^{84}$ Many cities have attempted to hire more workers from minority groups. ${ }^{85}$ Such programs would seem to bear a more realistic possibility of enhancing cooperation between city workers and the citizens whom they serve.

\section{An Analogous Substantial Relation Challenge: Sugarman v. Dougall}

The landmark decision of Sugarman v. Dougall ${ }^{86}$ involved a statute which required United States citizenship as a condition of municipal employment. ${ }^{\$ 7}$ In attempting to uphold the citizenship restriction,

than residents. Nonresidents who commute to homes outside the city can perform law enforcement functions during commutation. In addition, nonresident police officers may frequent local establishments, such as bars and retail stores after work hours, thus adding to off-duty police presence.

84. The New York City police department, for example, initiated a "Cop of the Block" program in 1971 to encourage informal contact between police and local residents in the Bedford-Stuyvesant area of Brooklyn. Under the program, policemen visit local homes and businesses while on duty to become acquainted with area residents. See N.Y. Times, Jan. 29, 1975, at 37, col. 1. See also TimE, Apr. 21, 1975, at 33, col. 3 (describing similar program sponsored by the Riverside, Cal. police dep't).

85. Some cities have suggested that residency requirements result in reduction of the high unemployment rates of inner city minority groups. Two courts have accepted this rationale without engaging in any analysis of its validity. Ector v. City of Torrance, 10 Cal. 3d 129, 135, 514 P.2d 433, 436, 109 Cal. Rptr. 849, 852 (1973); Abrahams v. Civil Serv, Comm'n, 65 N.J. 61, 72, 319 A.2d 483, 489 (1974). There is, of course, no necessary correlation between residency restrictions and the appointment of employees from minority groups. Any increase in minority representation depends upon the hiring policies of the city. See Abrahams v. Civil Serv. Comm'n, 65 N.J. 61, 88, 319 A.2d 483, 497 (1974) (Pashman, J., dissenting). Pittsburgh, for example, which long has had a residency law, has experienced over the last seven years a decline in the proportion of black policemen on its force. Detroit has recorded substantial gains, attributed most plausibly not to its residency requirement but to hiring procedures which require that blacks constitute one-half of each new police academy class. N.Y. Times, Aug. 11, 1974, at 1, col. 6 , at 35 , col. 1 .

86. 413 U.S. 634 (1973).

87. The citizenship requirement invalidated in Sugarman, N.Y. Civil SERv. Law \$ 53(1) (McKinney 1973), barred noncitizens of the United States from appointment as municipal employees, just as the residency requirements prohibit nonresidents from holding public jobs. From the viewpoint of the city or state, both noncitizen and nonresident are "outsiders." Because of his status as an outsider the attempt is made to exclude the nonresident from public jobs, though this is not to suggest that nonresidents constitute a suspect class.

The language of the New York State citizenship statute was strikingly similar to that of many residency requirements. Compare N.Y. CiviL SERv. LAw \$ 53(l) (McKinney 1973) with Chicago, Ill., Code $\$ 25-30$ (1939) and Pittsburgh, Pa., Charter Ordinance 450, 
New York State offered purposes largely identical to those offered to sustain municipal employee residency laws. In striking down the citizenship requirement, the Sugarman Court may have invoked the substantial relation test. The considerations applied in Sugarman thus may be relevant to judicial review of municipal residency restrictions.

While some commentators view Sugarman as a strict scrutiny alienage case, ${ }^{88}$ it is possible to view the decision as an example of substantial relation equal protection analysis. Significantly, the Court avoided the use of the term "suspect classification," referring to the concept only obliquely with its citation of Graham $v$. Richardson.89 The absence of the term is particularly puzzling in that the Supreme Court decided on the same day another alienage case, In re Griffiths, in which the Court repeatedly called alienage a suspect classification, ${ }^{01}$ using it to trigger the strict scrutiny standard of statutory review. Arguably, the Court in Sugarman ignored the term "suspect classification" because it was not at the analytical core of the opinion. ${ }^{02}$

The Sugarman opinion does seem to follow the substantial relation test. The Court recognizes, for example, the state's interest in limiting participation in government to members of the political community, ${ }^{93}$ but holds that "a flat ban on the employment of aliens in positions that have little, if any, relation to a State's legitimate interest, cannot

$\S 42$ (1902). The citizenship statute also allowed waivers, as do many residency laws, should a shortage of "qualified personnel" arise. Compare N.Y. Civil SERv. LAW $\$ 53(2)$

- (Mckinney 1973) with Cincinnati, OHio, Cone art. XVII, $\$ 1$ l(c) (1967). See also Krzewinski v. Kugler, 338 F. Supp. 492, 503 (D.N.J. 1972) (waiver of residency requirements is valid if a shortage of qualified personnel arises).

The analogy between citizenship and residency requirements for municipal employees was recognized in Hanson v. Unified School Dist., 364 F. Supp. 330, 332 (D. Kan. 1973) ("this kind of [residency] classification bears a resemblance to . . . citizenship requirements discussed in Sugarman..."). However, other post-Sugarman residency requirement cases do not allude to Sugarman.

88. See, e.g., Das, Discrimination in Employment Against Aliens-The Impact of the Constitution and Federal Givil Rights Laws, 35 U. PITT. L. REV. 499 (1974).

89. Graham v. Richardson, 403 U.S. 365 (1971), cited in Sugarman v. Dougall, 413 U.S. 634, 64I (1973). Graham held that classifications based on alienage were subject to strict judicial scrutiny because alienage was a "suspect classification."

90. 413 U.S. 717 (1973).

91. $I d$. at 721,725 .

92. One commentator suggests that the majority in Sugarman may have avoided the words "suspect classification" merely to persuade Chief Justice Burger to join their ranks. Das, supra note 88 , at 504 n.38. This suggestion, though somewhat appealing, perhaps is too facile. Chief Justice Burger, dissenting in Griffiths, seemed to have reservations about the type of analysis, as well as terminology, involved in use of strict scrutiny because of a suspect class:

In recent years the Court, in a rather casual way, has articulated the code phrase

"suspect classification" as though it embraced a reasoned constitutional concept.

Admittedly, it simplifies judicial work as do "per se" rules, but it tends to stop analysis while appearing to suggest an analytical process.

In re Griffiths, 413 U.S. 717,730 (1973) (Burger, C.J., dissenting).

93. 413 U.S. at 642 , quoting Dunn v. Blumstein, 405 U.S. 330,344 (1972). 
withstand scrutiny under the Fourteenth Amendment."94 Sugarman embarks on a full analysis of the efficacy of the means taken to effectuate the state legislative aims. ${ }^{95}$

The justifications offered in Sugarman to sustain the citizenship requirement are similar to the rationales offered in employee residency litigation. The state first argued that aliens, subject to sudden deportation or to conscription by their own countries, were less likely to remain as permanent employees. ${ }^{96}$ This assumption roughly parallels the emergency duty rationale for residency restrictions, which has the unexamined presumption that nonresidents are less likely to be available for work when urgently needed. Courts considering municipal employee residency laws should find instructive the response of the Sugarman Court to the availability argument. The Supreme Court noted: " "There is no offer of proof on this issue and [the state] would be hard pressed to demonstrate that a permanent resident alien ... would be a [poor] risk for a career position. . . ."97 Sugarman called for more than hypothetical facts, and courts considering residency restrictions for municipal employees likewise should demand proof that residency laws actually further legitimate purposes.

Confronted next by the public coffer doctrine, the Sugarman Court rejected it as inapposite. ${ }^{98}$ The case is an explicit abandonment of the early Supreme Court decisions ${ }^{99}$ which developed the public coffer rationale in the context of public employment. Sugarman questions whether the citizenship requirement furthered public coffer objectives since aliens, like citizens, pay taxes. ${ }^{100}$ Just as Sugarman categorically rejected the applicability of the public coffer doctrine in citizenship cases, so should the courts in residency litigation.

The final rationale offered by the state in Sugarman was that of "identity," in this case political identity. New York State argued that

94. 113 U.S. at 647 (emphasis added).

95. Id. This reading of Sugarman as reflective of the substantial relation standard of revicw is consistent with the Court's apparent preference to avoid invocation of the strict scrutiny test if at all possible. See Gunther, supra note 55, at 17-20; Note, The Iriebuttable Presumption Doctrine, supra note 56, at 1535 n.9; notes 56, 58 supra.

515. 413 U.S. at 645 .

97. Id., citing Dougall v. Sugarman, 339 F. Supp. 906,909 (S.D.N.Y. 1971).

98. Following the Graham and Shapiro holdings, the Court held that the public coffer doctrine had "no applicability in this case." 413 U.S. at 645.

99. People v. Crane, 239 U.S. 195, affirming 214 N.Y. 154, 108 N.E. 427 (1915); Heim v. McCall, 239 U.S. 175 (1915). In Heim and Crane, the Court upheld state statutes prohibiting the employment of aliens on public works. In a classic formulation of the public coffer theory, Justice Cardozo, then a judge of the New York Court of Appeals, declared: "The state in determining what use [sic] of its own moneys may legitimately consult the welfare of its own citizens rather than that of aliens." 214 N.Y. 154, 164, 108 ‥E. 427,430 (1915).

100. 413 U.S. at 645 . 
civil servants participate in the formulation of governmental policy and so must be free of competing obligations to a foreign power.101 Implicit is the familiar assumption that outsider's lack sufficient stake in and undivided commitment to a municipal entity. The Court accepted the "require[ment of] citizenship as a qualification for office"102 but rendered the statute void as applied to municipal employees. Sugarman thus indicates that residency restrictions might be valid for local officers. ${ }^{103}$ But in light of Sugarman, the political identity rationale cannot justify residency restrictions for employees, whether clerical personnel, sanitation workers, police or firemen.

In short, the municipal employee citizenship requirement at issue in Sugarman fell because of the insubstantial and conjectural rationales advanced for it. There was little evidence that the law substantially furthered the statutory objectives. Such infirmities pervade the purposes of residency requirements for municipal employees as well. Sugarman thus may serve as an analogy for litigation involving a related class of outsiders-the nonresident.

\section{Conclusion}

Municipal employee residency requirements are imposed by cities throughout the United States. The restrictions arguably violate the fundamental interest of municipal employees in freedom to travel, specifically, in freedom to migrate and settle outside city limits. Yet the designation of the right to travel as a fundamental interest in such a setting raises unsettled doctrinal questions concerning "intrastate" travel and postappointment durational requirements. Because of these uncertainties, the Court may prefer to use the substantial relation equal protection test. By this test, the classification of residents and nonresidents and discrimination between them in municipal employment must substantially advance the purposes offered in support. As this Note suggests, there is serious question whether the residency requirements in fact substantially further their putative purposes. Residency restrictions thus often may be invalid as a denial of equal protection.

101. Id. at 641 .

102. Id. at 647 (emphasis added).

103. See note 2 supra. 